\title{
MAPPING SPATIOTEMPORAL DISTRIBUTION OF MANGROVES IN MAFIA ISLAND IN TANZANIA USING LANDSAT IMAGERY
}

\author{
J.S.Mayunga* and G.A. Uhinga \\ Center for Information and Communication Technology (CICT), Ardhi University, P. O. Box 35176, Dar es Salaam, Tanzania, \\ mayungax@gmail.com, guidouhinga@gmail.com.
}

Commission IV, WG IV/4

KEY WORDS: Mapping; Mangroves; Satellite Image; Landsat; Mafia Island

\begin{abstract}
:
Mangroves are important for survival of coastal communities as they provide ecosystem services that support coastal population and their livelihoods. Most coastal communities largely depend on ecosystem services provided by mangroves such as fuel wood, building poles, charcoal, and also mangroves provide spawning ground for coastal fishes. Most importantly mangroves act as a buffer that protects coastal communities from natural hazards such as tropical storms, strong winds, beach erosion, and even tsunami. Despite the important role that mangroves play, yet mangroves are under serious threat to extinction worldwide. Many mangrove-rich developing countries, including Tanzania, are facing challenges in establishing effective management plans to protect increasingly threatened mangrove ecosystems. Most of these challenges are associated with inadequate or nonexistent of up-to-date and accurate geospatial information. Knowledge on extent and spatial distribution of mangroves is critical in planning and effective management of mangroves. The aim of this study was to assess the spatial and temporal distribution of mangroves in Mafia Island using remotely sensed data for three decades (1985-2013). Results revealed a decrease of mangroves from 3,708.36 ha in 1985 to 3,187.25 ha in 2013. From the spatiotemporal dimension point of view, the results show that overall mangroves in Mafia Island have been gradually decreasing over time. This trend suggests a decline rate of about $14 \%$ for the period of 28 years, which is an average rate of $0.5 \%$ per year. This rate of mangrove loss should not be underestimated; effective protection measures and sustainable utilization of mangrove resources are needed.
\end{abstract}

\section{INTRODUCTION}

Mangroves are important for survival of coastal communities as they provide ecosystem services that support coastal population and their livelihoods. Most coastal communities depend heavily on ecosystem services provided by mangroves. For example, mangroves provide spawning ground for coastal fishes (Wang et al. 2003 and Kuenzer et al. 2011) as well as useful products such as fuel wood, building poles, charcoal, tannin and traditional medicines. Most importantly mangroves act as a buffer that protects coastal communities from natural hazards (Chen et al. 2013) such as tropical storms, strong winds, beach erosion, and even tsunami (Spalding et al. 2014, Mchenga and Ali 2015). Mangroves are also known as blue carbon sinks because they can transfer and store carbon in their sediments more than those of terrestrial forests (Rhyma 2016, Kiruia et al. 2013 and Lawrence 2012). Despite the important role that mangroves play, yet mangroves are under serious threat to extinction in many parts of the world (Helliwell et al. 2004), particularly in developing countries. Threats on mangroves are projected to increase due to the increasing anthropogenic activities, sea-level rise and climate change. Globally, it is estimated that about $35 \%$ of mangroves has been lost from 1980 to 2000 (Giri et al. 2011 and Kuenzer et al. 2011). This rate is expected to increase, especially in developing countries due to anthropogenic pressures such as over-harvesting of mangroves for timber and fuel-wood production, aquaculture activities and salt-pond constructions (Kairo et al. 2001). It is predicted that if the current rate of mangrove clearance continues worldwide, all mangroves could disappear in the next 100 years (Duke et al. 2007).

\footnotetext{
${ }^{1}$ *Corresponding author
}

Mangroves in Mafia Island are under high pressure and threatened by increasing anthropogenic activities that contribute to high rate of mangrove depletion. Tanzania like many other mangrove-rich developing countries is facing challenges in establishing effective management plans to protect increasingly threatened mangrove ecosystems. Most of these challenges are associated with inadequate or nonexistent of up-to-date and accurate geospatial information. For example, the only estimation of spatial extent of mangroves coverage in the Island was that of 1989 inventory (Semesi 1992). Spatial and temporal distribution of mangroves in the Island is currently not known. Therefore the aim of the present study was to quantify and map the extent and spatiotemporal distribution of mangroves in the Island using LANDSAT imagery in order to enhance spatial information for mangroves protection and management. The basic reserch questions guiding this paper are: 1)How many hectares of mangroves have been cleared for the past three decades?; 2)What have been the major causes of mangrove forest deforestation in Mafia Island for the past three decades?; and 3)How do the results help to guide planning and policy formulation for mangrove management?

\section{MANGROVES MANAGEMENT INITIATIVES IN TANZANIA}

Previous studies reported that there are nine mangrove species found in Tanzania (Haule 2003, Helliwell et al. 2004 and Mangora 2011), all of which are also present in Mafia Island. These mangroves species are:1) Rhizophora mucronata, 2) Ceriops tagal,3) Avicennia marina, 4) Bruguieria gymnorrhiza, 5) Heritiera littoralis, 6) Lumnitzera racemosa, 7) Sonneratia alba, 8) Xylocarpus granatum, and 9) Pemphis 
acidula. Mangroves in Tanzania are found on the coasts of Tanga, Kilwa, Lindi, Muheza, Bagamoyo, Kisarawe, Mtwara and the delta of the Rufiji River, including Mafia Island (Wang et al. 2003). The last estimation of coverage area of mangroves in Tanzania Mainland was done in 2000 which estimated that Tanzania mainland has a total of 108,138 ha (Wang et al. 2003). However, this estimation did not include mangroves in Mafia Island (Table 1). Mangroves in Tanzania are gazetted as forest reserve since 1928 (Wang et al. 2003). Hence, they are protected areas of land by government law to regulate and control extraction and to ensure sustainable management of mangrove ecosystems and services (Mangora 2011). Historically, the government of Tanzania has been developing various initiatives to ensure protection and sustainable management of mangroves in the country. In 1988, the government established a national wide Mangrove Management Plan (MMP) to monitor mangrove habitats over time and prepare effective management plans. In 1995, a large part of mangrove ecosystems in Mafia Island became under the protection of the Mafia Island Marine Park (MIMP) (Helliwell et al. 2004 and Lewis et al. 2011). The MIMP initiative was established by the government under the Fisheries Act of 1970, which declared all small areas of reef in the country, including those in Mafia Island as Marine Reserves for total protection. The MIMP in the Island covers an area of 1,745 ha (Lewis et al. 2011), which is about $2 \%$ of the total area of the Island. In 2004, Mafia Island became part of the Rufiji-Mafia-Kilwa Marine Ramsar site (Helliwell et al. 2004), which further called for protection of all coastal areas, including mangroves in the Island. Table 1 summarizes the government initiatives to protect mangrove forest in Mafia Island for the period between 1985 and 2013.

\begin{tabular}{|l|l|l|}
\hline Period & Year & $\begin{array}{l}\text { Government Initiatives to } \\
\text { Protect Mangroves in Mafia }\end{array}$ \\
\hline $1985-1995$ & 1987 & $\begin{array}{l}\text { Tanzania Forest Division declared } \\
\text { a ban on cutting mangroves }\end{array}$ \\
\cline { 2 - 3 } & 1988 & $\begin{array}{l}\text { Establishment of Mangrove } \\
\text { Management Plan (MMP) }\end{array}$ \\
\hline $1995-2006$ & 1995 & $\begin{array}{l}\text { Establishment of Mafia Island } \\
\text { Marine Park (MIMP) }\end{array}$ \\
\cline { 2 - 3 } & 2002 & $\begin{array}{l}\text { Tanzania Forest Act allowed } \\
\text { cutting of mangroves with a } \\
\text { permit }\end{array}$ \\
\cline { 2 - 3 } & 2004 & $\begin{array}{l}\text { Mafia Island became part of the } \\
\text { Rufiji-Mafia-Kilwa Marine } \\
\text { Ramsar site }\end{array}$ \\
\hline $2006-2013$ & 2006 & $\begin{array}{l}\text { No recorded initiatives during this } \\
\text { period }\end{array}$ \\
\cline { 2 - 3 } & 2013 & $\begin{array}{l}\text { No recorded initiatives during this } \\
\text { period }\end{array}$ \\
\hline
\end{tabular}

Table 1. Summary of government initiatives to protect mangroves in Mafia Island

\section{MANGROVE LOSS IN TANZANIA}

Mangrove loss in Tanzania is well documented by Semesi (1992) and Wang et al (2003).Their findings show that for the period between 1989 and 2000 mangroves in Tanzania decreased from $115,475.6$ ha to 108,138 ha. This is a decrease of $7,337.6$ ha or $6 \%$ for the period of ten years (Table 2). The data in Table 2 show that for the period of ten years, mangroves in Pangani, Dar es Salaam, Kisarawe, and Mtwara have slightly increased due to various restoration and sustainable utilization programmes. Conversely, the data show that mangroves in Mkinga \& Tanga, Bagamoyo, Rufiji, Kilwa and Lindi are declining. Important to note is that mangroves in Pangani have more than doubled for the past ten years while the highest rate of mangrove loss was observed in Lindi $(-11 \%)$ followed by Bagamoyo (-10\%) and Rufiji delta (-10\%).

\begin{tabular}{|l|l|l|l|}
\hline Region/District & $\mathbf{1 9 8 9}$ & $\mathbf{2 0 0 0}$ & $\mathbf{1 9 8 9 - 2 0 0 0}$ \\
\hline & $\begin{array}{l}\text { Mangrove } \\
\text { s coverage } \\
\text { area(ha) }\end{array}$ & $\begin{array}{l}\text { Mangrov } \\
\text { es } \\
\text { coverage } \\
\text { area(ha) }\end{array}$ & $\begin{array}{l}\text { Rate of } \\
\text { loss/gain of } \\
\text { mangroves } \\
(\%)\end{array}$ \\
\hline Mkinga \& Tanga & $9,403.3$ & 9,313 & -1 \\
\hline Pangani & $1,755.6$ & 3,879 & +121 \\
\hline Bagamoyo & $5,635.8$ & 5,051 & -10 \\
\hline Dar es Salaam & $2,168.2$ & 2,516 & +16 \\
\hline Kisarawe & $3,858.3$ & 4,092 & +6 \\
\hline Rufiji & $53,254.8$ & 48,030 & -10 \\
\hline Mafia & $3,472.9$ & - & - \\
\hline Kilwa & $22,438.7$ & 21,755 & -3 \\
\hline Lindi & $4,546.5$ & 4,044 & -11 \\
\hline Mtwara & $8,941.5$ & 9,458 & +6 \\
\hline Total & $115,475.6$ & 108,138 & -6 \\
\hline
\end{tabular}

Table 2. Mangroves loss in Tanzania for the period between 1989 and 2000. Source: Semesi (1992) and Wang et al., (2003)

\section{DATA AND METHODOLOGY}

\subsection{The Study Area}

Mafia Island is one of the six districts that form the Coast Region in Tanzania and it covers an area of $972 \mathrm{~km}^{2}$, of which $407 \mathrm{~km}^{2}$ is dry land and $565 \mathrm{~km}^{2}$ is covered by water. Mafia Island and its chain of small islets lie approximately $120 \mathrm{~km}$ south of Dar es Salaam city and $20 \mathrm{~km}$ offshore from the eastern extent of the Rufiji Delta, which is the largest mangrove forest in the eastern Africa region (Semesi 1992). The Mafia main Island is about $48 \mathrm{~km}$ long and $17 \mathrm{~km}$ wide at its widest point (Lewis et al. 2011). Islets are mainly scattered to the west and south of the main Island and virtually lacking on the eastern and northern sides of the main Island. The southern part of the Island is under the conservation program through the Mafia Island Marine Park (MIMP). Natural vegetations on Mafia Island include the tidal mangrove thickets and scrubby coastal moorlands. According to the 2012 Tanzania housing and population census, the population of the Island was 46,438 (URT 2012). Figure 3 depicts the location of Mafia Island in Tanzania. 


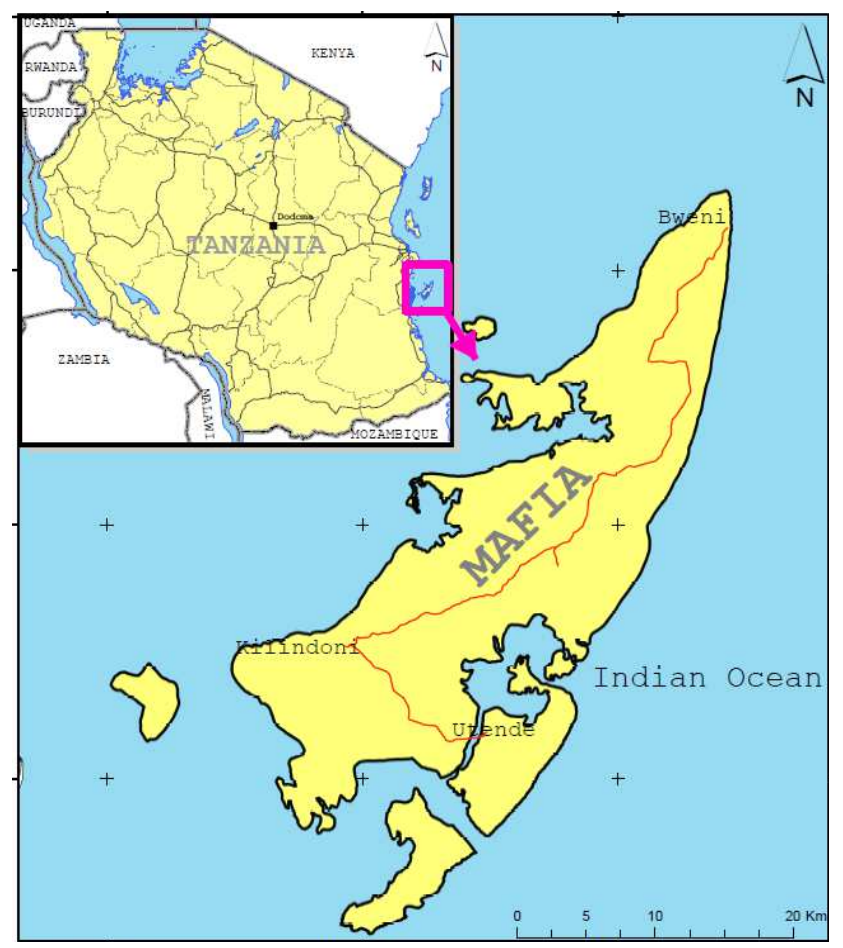

Figure 3. Mafia Island Location Map

\subsection{Data}

A set of Landsat images (Landsat 5 and Landsat 8 OLI) were used to quantify the mangrove forest changes in Mafia Island for three decades (1985-1995; 1995-2006; and 2006-2013). The Landsat 5 images were acquired for year 1985, 1995 and 2006 while Landsat 8 OLI image was acquired for year 2013. The Landsat TM data have seven spectral bands, with a spatial resolution of $30 \mathrm{~m}$ for bands $1-5$ and 7 . The Landsat 8 OLI data have nine spectral bands with a spatial resolution of $30 \mathrm{~m}$ for bands 1-7 and 9. The images were obtained free of charge from United States Geological Survey (USGS) and the Regional Center for Mapping of Resources for Development (RCMRD). Data for image classification and ground truthing for accuracy assessment were collected using a Hand Held Global Positioning Systems (GPS) with a horizontal accuracy of \pm 10 meters.

\subsection{Methods}

There are several open source software available for GIS analysis and image processing, that are very good alternatives to commercial software e.g., ILWIS, QGIS and GRASS. In this study we used ILWIS software for image processing and ArcGIS software which is commercial software for preparation of final output maps. Analysis of the satellite images involved the following processes: Georeferencing of the satellite images, Preparation of sample site map (Training site), Classification of the satellite images, Accuracy assessment of the classification results and generation of spatial extent map. Figure 4 depicts the Flowchart of the methodological procedures used in this study. The images were georeferenced using four control points extracted from Mafia Island topographic map sheet at a scale of 1:50,000. The control points were used to georeference all individual image bands of the images. The images were registered to the Universal Transverse Mercator System (UTM), Zone $37 \mathrm{~S}$, and Datum Arc 1960. Mafia Island falls in two images scenes; therefore the georeferencing process enabled mosaicking of the satellite images from the two scenes (northern and southern parts of the Island). Training for image classification was done based on the GPS data collected from the field and the expert knowledge of mangrove areas in the Island. We used exiting land use maps and high resolution images (Google earth) to preliminary identify land cover types in the study area before the field data collection. Two files were created during the training exercise. One file was used as a training set for image classification while the other file was used for ground truthing to assess the accuracy of the classification results.

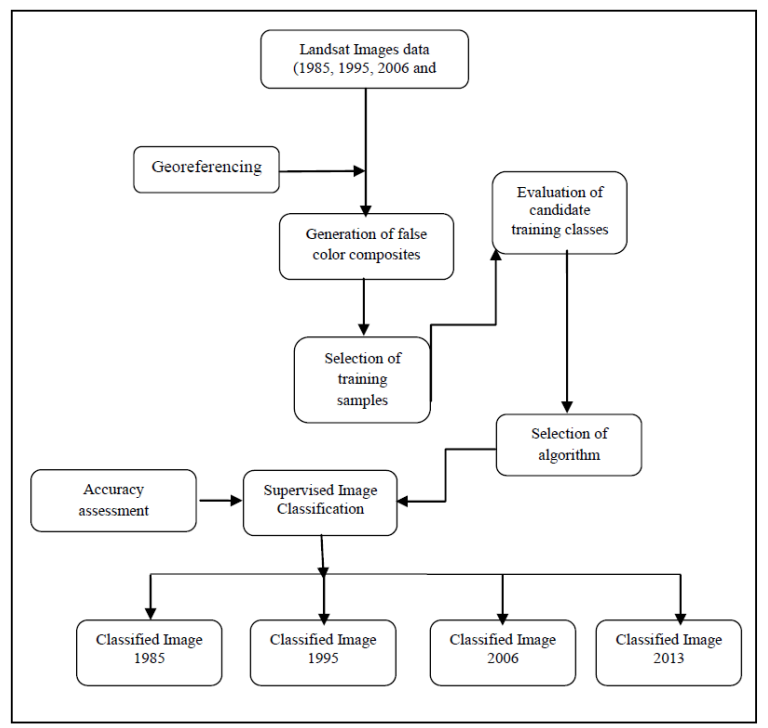

Figure 4. Flowchart of the methodological procedures used to analyzed mangrove forest

Supervised image classification using maximum likelihood algorithm was carried out to classify the colour composite images using the following band combination: band 5(Red), 6(Green), 3(Blue). The classification process was done using the two training sample site files. Maximum likelihood algorithm was chosen because it has a well-developed theoretical base and it is more accurate than the other algorithms such as box algorithm, minimum distance to mean and minimum mahalanobis distance algorithm (Bolstad 1991 and Chen et al. 2013). Confusion matrix/Standard Error Matrix established by using sample site data and ground truthing data was used to assess the accuracy of classification results. The final output of the classification process was mangrove spatial distribution maps for the years 1985, 1995, 2006, and 2013.

\section{RESULTS AND DISCUSSION}

Results of the accuracy assessment indicated a satisfactory rate of classification accuracy with an overall accuracy of $82.14 \%$ based on the maximum likelihood classification algorithm. The results further show a user accuracy of $90.30 \%$ and producer accuracy of $67.23 \%$.

The colour composite scheme allowed mangroves to be easily detected in the image. In the colour composite generated, mangroves appear in dark red since they have a high reflectance in the Near Infrared band. Figure 5 shows selected mangrove sites along the western coast of the Island. The dark red colored areas on the images represent the distribution of healthy mangrove forest. The green areas on the map show the spatial distribution of mangroves in the Island. 


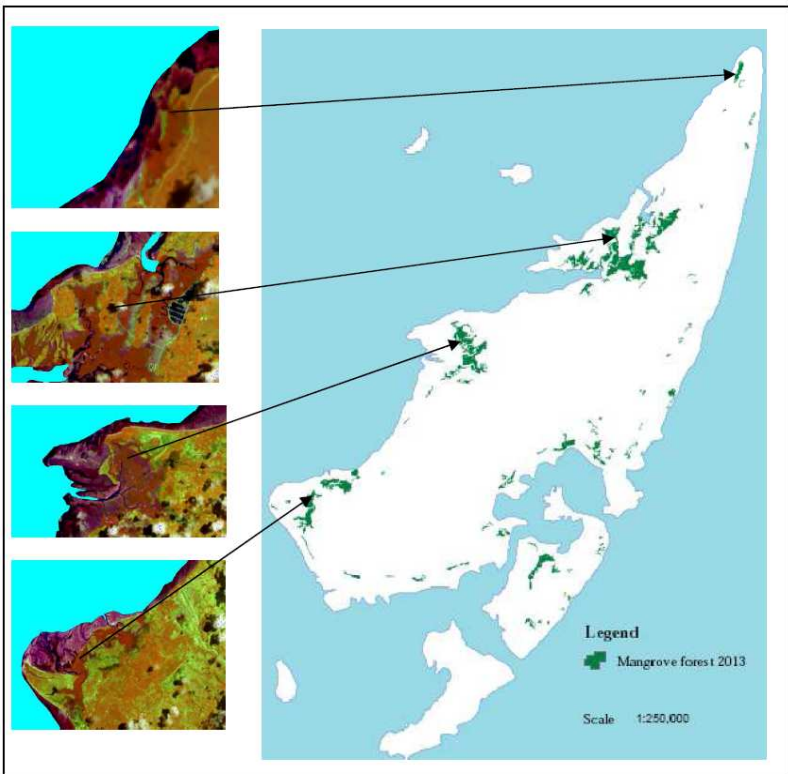

Figure 5. Sections of colour composite of mangrove rich areas in Mafia Island and the final output map of classified images showing distribution of mangrove in the year 2013

The results of spatiotemporal distribution of mangroves in Mafia Island reflecting the trend of about three decadal of changes (28 years) are presented in Figure 6. The image classification results indicate that most mangroves are found in the western and southern part of the Island. There are few mangroves in the northern part of the Island while there is almost none in the eastern part of the Island where the Mlola Forest Reserve is located. From the spatiotemporal dimension point of view, the classification results show that overall mangroves in Mafia Island have been gradually decreasing over time. Table 7 summarizes the estimated area coverage of mangrove forest in Mafia Island for three decades. The classification results show that approximately $3,708.36$ ha of mangroves existed in 1985, while about 3,671.07 ha existed in 1995. In 2006 the study estimated area coverage of $3,438.16$ ha of mangroves and in 2013 there were 3,187.25 ha. From 1985 to 2013 , the trend suggests a loss of 521.11 ha of mangroves in the Island which is about $14 \%$ or $0.5 \%$ per year.

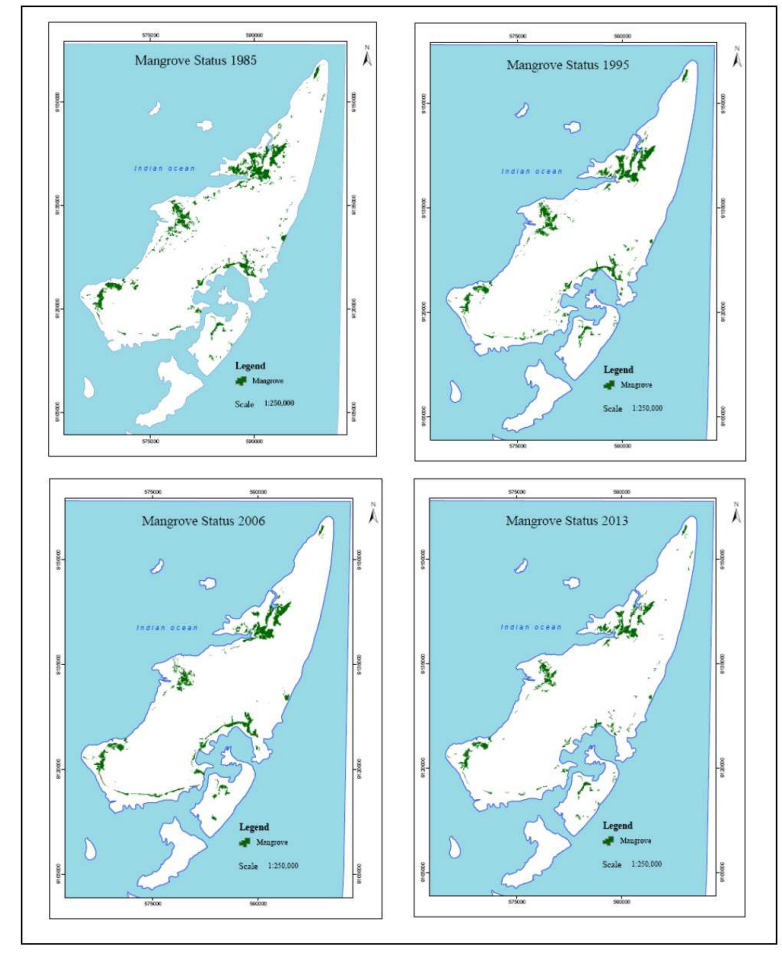

Figure 6. Spatial distribution of mangroves in Mafia Island in 2013

\begin{tabular}{|l|c|c|c|c|}
\hline Year & $\mathbf{1 9 8 5}$ & $\mathbf{1 9 9 5}$ & $\mathbf{2 0 0 6}$ & $\mathbf{2 0 1 3}$ \\
\hline Estimated & & & & \\
$\begin{array}{l}\text { Mangrove } \\
\text { Forest } \\
\text { Area (ha) }\end{array}$ & $3,708.36$ & $3,671.07$ & $3,438.16$ & $3,187.25$ \\
\hline
\end{tabular}

Table 7. Summary of status of mangrove forest area extent in Mafia Island from 1985-2013

Results further show that decline of mangroves in the Island is largely contributed by increasing anthropogenic activities such as aquiculture. In recent years, aquaculture has become an increasing business in the Island and if this business is not properly controlled, there is the potential for massive degradation of mangroves in the Island. Studies show that shrimp farming in Eastern Africa region is becoming a biggest threat to mangroves (Kairo et al.2001). Our study confirms earlier findings that mangroves in many parts of the country are generally declining (Mangora 2011 and Wang et al. 2003). Furthermore, our findings are consistent with that of Lewis et al. (2011) who noted some evidence of human impacts on mangroves in Chole, the area that is completely located within the Mafia Marine Park.

Overall results show that for the past three decades the trend of mangrove forest in Mafia Island has been decreasing. However, for the period between 2006 and 2013 there was a dramatic decrease of mangroves in the Island. The high rate of mangrove loss for the period between 2006 and 2013 can be associated with mainly two factors: lack of sustainability of most donor funded conservation projects established during the period between 1985 and 2006 and increasing development of aquaculture activities in the Island. Shrimp farming was identified as a major cause of direct and indirect loss of mangrove ecosystems in the island due to deforestation for pond construction. Figures 8 and 9 show the progressive destruction of mangrove forest due to shrimp farming in the Island. 


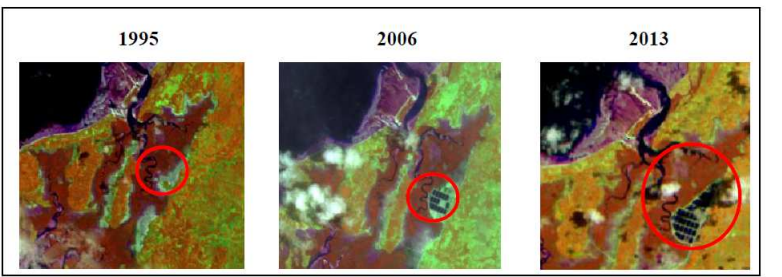

Figure 8 Mangrove clearance due to Shrimp Farming in Mafia Island

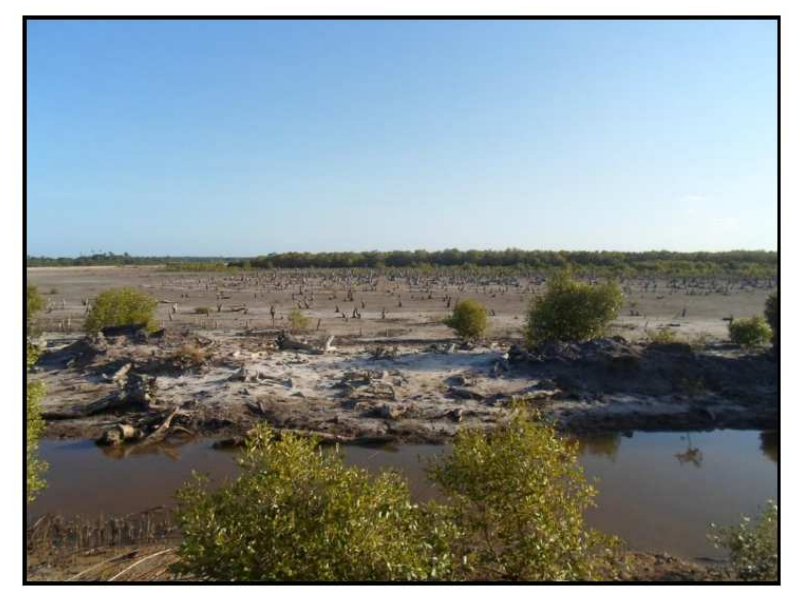

Figure 9. The photo depicts widespread mangrove clearance for shrimp farming in Mafia Island. The photo was taken in March, 2015.

Results further suggest that mangroves in the Island are declining but not at a very high rate. The rate of mangroves loss in the Island is estimated to be $0.5 \%$ per year. This rate is relatively lower than that of the Tanzania mainland which is estimated to be $0.6 \%$ per year. However, the average annual rate of decline of $0.5 \%$ should serve as a wakeup call to the government. More efforts must be taken to ensure effective protection of the threatened mangroves, not only in the Island but also across the country.

\section{CONCLUSION}

There is still inadequate geospatial information for effective mangrove planning and management in the Island. The spatial information generated in this study may help the decision making processes for rehabilitation and conservation efforts that are currently needed to protect and restore the depleted mangroves in the Island. Most importantly the existing mangrove policy and management plans could be improved by utilizing the geospatial information and the maps generated by this study. However, our results should be interpreted with caution as LANDSAT are low resolution satellite imagery which may underestimate the mangrove area coverage. Further studies on mapping mangrove spatial and temporal distribution in the Island should focus on the use of high resolution satellite imagery in order to improve the mangrove coverage estimation. This study contributes to our understanding on the status of mangroves coverage, mangrove losses and its underlying causes and the need to improve and strengthen the current planning and management programmes and initiatives in the Island.

\section{ACKNOWLEDGEMENTS}

The study was funded by SERVIR-Eastern and Southern Africa, which is a joint initiative of USAID (United States Agency for International Development) and NASA (National Aeronautics and Space Administration). The SERVIR-Eastern and Southern Africa is implemented in partnership with RCMRD (Regional Center for Mapping and Resources Development). The financial support is gratefully acknowledged. However, the findings, conclusions, and opinions expressed in this paper are solely those of the authors.

\section{REFERENCES}

Bolstad, P., Lillesand, T.M., 1991. "Rapid maximum likelihood classification." Photogrammetric Engineering \& Remote Sensing 57(1), pp.67-74.

Chen, C., Son, N., Chang, N., Chen, N., Chang, L., Valdez, M., Centeno, G., Thompson, C., and Aceituno, J., 2013. "MultiDecadal Mangrove Forest Change Detection and Prediction in Honduras, Central America, with Landsat Imagery and a Markov Chain Model." Remote sensing 5, pp. 6408-6426. https://doi.org/10.3390/rs5126408.

Duke, N.C., Meynecke, J. O., Dittmann, S., Ellison, A. M., Anger, K., Berger, U., Cannicci, S., Diele, K., Ewel, .C., Field, C.D., Koedam, N., Lee, S.Y., Marchand, C., Nordhaus, I. and Dahdouh-Guebas, F., 2007. "A world without mangroves?" Science 317: 5834, pp. 41-42. http://hdl.handle.net/10453/14847.

Giri1,C., Ochieng, E., Tieszen, L., Zhu, Z., Singh, A., Loveland, T., Masek, J., and Duke, N., 2011. "Status and distribution of mangrove forests of the world using earth observation satellite data." Global Ecology and Biogeography 20, pp.154-159. https://doi.org/ 10.1111/j.1466-8238.2010.00584.x.

Green, E.P., Clark, C.D., Mumby, P. J., Edwards, A. J., and Ellis, A. C., 1998. "Remote sensing techniques for mangrove mapping." International Journal of Remote Sensing 19(5), pp.935-956. ://doi.org/10.1080/014311698215801.

Helliwell, K., Tichler, M. and Cacre, E. 2004. "Tanzania Forest Research Programme, Utende Village, Mafia Island, Tanzania.” TZF Phase 142 Science Report, Frontier.

https://frontiergap.com/Publications/Files (20 December, 2016)

Kairo, J. D., Dahdouh-Guebas, F., Bosire. J., and Koedam, N. 2001. "Restoration and Management of Mangrove Systems: A lesson for and from the East African region." South African Journal of Botany 67, pp.383-389.

Kuenzer, C., Bluemel ,A., Gebhardt, S., Quoc, T., and Dech, S. 2001. "Remote Sensing of Mangrove Ecosystems: A Review.” Remote Sensing 3, pp.878-928. https://doi.org/10.3390/rs3050878.

Lewis, E., Margerison, B., Sobkowiak, B. and Fanning, E. 2011. "Assessing the health of Mafia Island's marine ecosystems." Frontier Tanzania Environmental Research Report 129. The Society for Environmental Exploration, London, UK. http://frontier-dk.org/Publications/Files/2011_083.pdf (16 March 2017).

Lawrence, A. 2012. "Blue Carbon: A new concept for reducing the impacts of climate change by conserving coastal ecosystems 
in the Coral Triangle.”WWF report, Brisbane, Queensland, WWF-Australia. http://www.taccire.suanet.ac.tz /(10 June 2017).

Mangora, M.M. 2011. "Poverty and institutional management stand-off: a restoration and conservation dilemma for mangrove forests of Tanzania." Wetlands Ecology and Management, 19, pp. 533-54. https://doi.org/10.1007/s11273-011-9234-2.

Mchenga, I.S.S. and Ali A.I. 2015. "A review of status of mangrove forest in Zanzibar Island, Tanzania." International Journal of Research and Review 2(8), pp.518-526. www.gkpublication.in

Rhyma, P., Norizah K ., Ismail Adnan A. M., and Shamsudin I. 2016. "A review of uses of satellite imagery in monitoring mangrove forests." Earth and Environmental Science 37, pp.114. https://doi.org/10.1088/1755-1315/37/1/012034.

Samoilys, M., Pabari, M., Andrew, T., Maina, G.W., Church, J.,Momany, A., Mibei, B., Monjane, M., Shah, A.,

Menomussaga, M. and Mutta, D., 2015. Resilience of Coastal Systems and their Human Partners in the Western Indian Ocean, Nairobi Conversion, Nairobi Kenya.

https://portals.iucn.org/library/sites/library/files/documents/201 5-019.pdf (22 May 2017).

Semesi, A. K. 1992. "Developing Management Plans for the Mangrove Reserves of Mainland Tanzania." Hydrobiologia 247, pp. 1-10.

Spalding, M., McIvor, A., Tonneijck, F.H., Tol, S. and Van Eijk, P. 2014. Mangroves for coastal defence: Guidelines for coastal managers \& policy makers. Wetlands International and the Nature Conservancy.

https://www.nature.org/media/oceansandcoasts/mangroves-forcoastal-defence.pdf (12 October 2017).

United Republic of Tanzania (URT) .2012. Population and Housing Census. National Bureau of Statistics, Ministry of Finance, Dar es Salaam, Tanzania http://www.nbs.go.tz/ .(15 April 2017).

Wang, Y., Bonynge, G., Nugranad, J., Traber, M., Ngusaru, A., Tobey, J., Hale, L., Bowen, R., and Makota, V., 2003. "Remote sensing of mangrove change along the Tanzania coast." Marine Geodesy 26, pp.1-2.

https://doi.org/10.1080/01490410390181243. 